\title{
The use of SI units
}

\author{
V. WRIGHT \\ From the University of Leeds
}

Throughout the United Kingdom SI units are being adopted in line with international practice. The following is a summary of the principles of SI units and outlines the main changes, so that authors may report their findings appropriately.

1 WHAT ARE SI UNITS

(1) SI stands for Système International and includes seven base units:

\begin{tabular}{|c|c|c|}
\hline Quantity & $\begin{array}{l}\text { Name of } \\
\text { SI unit }\end{array}$ & $\begin{array}{l}\text { Symbol for } \\
\text { SI unit }\end{array}$ \\
\hline Length & metre & $\mathrm{m}$ \\
\hline Mass & kilogram & $\mathrm{kg}$ \\
\hline Time & second & $\mathrm{s}$ \\
\hline Electric current & ampere & A \\
\hline $\begin{array}{l}\text { Thermodynamic } \\
\text { temperature }\end{array}$ & kelvin & $\mathrm{K}$ \\
\hline Luminous intensity & candela & $\mathrm{cd}$ \\
\hline
\end{tabular}

(2) Derived SI units are obtained by combination of these base units, thus allowing any physical quantity to be expressed in terms of SI units. Some derived SI units have special names and symbols, the more important ones being as follows:

\begin{tabular}{|c|c|c|}
\hline \multirow[b]{2}{*}{ Quantity } & \multicolumn{2}{|c|}{$\begin{array}{l}\text { Symbol for and } \\
\text { Name of definition of SI }\end{array}$} \\
\hline & SI unit & unit \\
\hline Force & newton & $\begin{array}{c}\mathrm{N}=\mathrm{kg} \cdot \mathrm{m} / \mathrm{s}^{2} \text { or } \\
\mathrm{kg} \cdot \mathrm{m} \cdot \mathrm{s}^{-2}\end{array}$ \\
\hline Pressure & pascal & $\begin{array}{c}\mathrm{Pa}=\mathrm{N} / \mathrm{m}^{2} \text { or } \\
\mathrm{N} \cdot \mathrm{m}^{-2}\end{array}$ \\
\hline $\begin{array}{l}\text { Work, energy, } \\
\text { quantity of heat }\end{array}$ & joule & $\mathrm{J}=\mathrm{N} \cdot \mathrm{m}$ \\
\hline Power & watt & $\mathrm{W}=\mathrm{J} / \mathrm{s}$ or $\mathrm{J} \cdot \mathrm{s}^{-1}$ \\
\hline
\end{tabular}

(3) The coherent SI unit of volume is the cubic metre but the litre is also recognized as a unit of volume and is exactly equal to one cubic decimeteri.e. 1000 litre $=1$ cubic metre. If any confusion could arise between the symbol for litre (1) and the figure 1, the word litre should be written in full. Concentrations should be expressed with the litre in the denominator:

Mass concentration $\mathrm{kg} / \mathrm{l}$

Amount of substance ('molar') concentration $\mathrm{mol} / \mathrm{l}$

(4) Decimal multiples and submultiples are formed with the following prefixes:

\begin{tabular}{|c|c|c|c|c|c|}
\hline Factor & Name & Symbol & Factor & Name & Symbol \\
\hline & & & $10^{-18}$ & atto & a \\
\hline & & & $10^{-15}$ & femto & f \\
\hline $10^{12}$ & tera & $\mathrm{T}$ & $10^{-12}$ & pico- & $\mathrm{p}$ \\
\hline $10^{9}$ & giga- & G & $10^{-9}$ & nano- & $\mathrm{n}$ \\
\hline $10^{6}$ & mega- & $M$ & $10^{-6}$ & micro- & $\mu$ \\
\hline $10^{3}$ & kilo- & $\mathrm{k}$ & $10^{-3}$ & milli- & $\mathrm{m}$ \\
\hline $10^{2}$ & hecto- & $\mathrm{h}$ & $10^{-2}$ & centi- & c \\
\hline $10^{1}$ & deca- & da & $10^{-1}$ & deci- & d \\
\hline
\end{tabular}

(i) The use of prefixes representing 10 raised to a power which is a multiple of 3 is especially recommended. The most widely used ones are kilo, milli, and micro. The symbol for a prefix acts as a convenient shorthand: e.g. $0 \cdot 000001 \mathrm{~g}=10^{-6} \mathrm{~g}=1 \mu \mathrm{g}$.

(ii) Compound prefixes should be avoided and only one prefix used in forming decimal multiples or submultiples: e.g. $10^{-9} \mathrm{~g}$ is $1 \mathrm{ng}$ not $1 \mathrm{~m} \mu \mathrm{g}$.

A consequence of this rule is that in derived units the prefix should be attached to one unit only, preferably in the numerator; the kilogram is an exception, as $\mathrm{kg}$ is the fundamental unit. Thus $1 \mu \mathrm{g} / \mathrm{ml}$ is better expressed as $1 \mathrm{mg} / 1$.

\section{RULES FOR USING UNITS}

(1) The symbol for a unit is unaltered in the plural and should not be followed by a full stop except at the end of a sentence: e.g. $5 \mathrm{~cm}$ not $5 \mathrm{~cm}$. or $5 \mathrm{cms}$.

(2) The solidus (/) or word 'per' should only be used once in each unit. Where necessary the negative index may be used: e.g. $\mathrm{ml} / \mathrm{min}$ or $\mathrm{ml} \mathrm{min}^{-1}$.

(3) The decimal sign between digits is indicated by a full stop in typing. No commas are used to divide large numbers into groups of three, but a half-space (whole space in typing) is left after every third digit. If the numerical value of the number is less than unity, a zero should precede the decimal sign: e.g. $0 \cdot 123456$ not $\cdot 123,456$.

(4) When expressing a quantity by a numerical value and a unit, it is in most applications advisable to use a multiple or submultiple which gives a simple whole number between 1 and 999: e.g. $10^{-5} \mathrm{~g}$ is best recorded as $10 \mu \mathrm{g}$ and not $0.01 \mathrm{mg}$.

(5) The SI symbol for 'day' (i.e. 24 hours) is 'd', but urine and faecal excretions of substance should preferably be expressed as 'per 24 hours' (e.g. g/24 h). Expressions as 'per day' (e.g. g/d) could be interpreted as meaning 'between the hours of sunrise and sunset'. 
3 LABORATORY REPORTS

A report of a measurement should always include the unit as well as the numerical value: e.g. plasma cholesterol can be reported as:

$$
\text { plasma cholesterol }\left\{\begin{array}{c}
\text { substance concentration } \\
=3.6 \mathrm{mmol} / 1 \\
\text { mass concentration } \\
=1.4 \mathrm{~g} / \mathrm{l}
\end{array}\right.
$$

To report this result as 'cholesterol $=1 \cdot 4$ ' is ambiguous.

\section{WHAT WILL CHANGE}

The main changes involve the units of concentration and pressure. The changes are of four types.

(1) For some tests the unit and symbol will change but the numerical value will be unaltered: e.g. blood platelets $=150000 / \mathrm{mm}^{3}=150 \times 10^{9} / 1$.

(2) For substances of defined chemical composition and known molecular weight, substance (or 'molar') concentration instead of mass concentration will be used. This is obtained by dividing the mass concentration (in grammes per litre) by the molecular weight. In some cases, the analyst refers to an atom, ion, or radical and in these cases the appropriate atomic, ionic, or radical weight is used and the nature of the particle specified. Thus barbiturate, folate, lactate, urate, etc., refer to the ionized radical, not to the acid or base itself.

(3) For substances of undefined composition or molecular weight it is impossible to use molar concentration, and for these mass concentration will continue to be used, but expressed as mass per litre, and not per $\mathrm{ml}$ or per $100 \mathrm{ml}$. This applies to all proteins except haemoglobin (see below, para 5 (1)).

Mass concentration will also be used for expressing plasma vitamin $B_{12}$ and folate measurements, as the molecular weight of the biologically active compound is uncertain.

(4) The SI unit of pressure is the pascal (symbol $\mathrm{Pa}$ ), which will eventually replace the very wide range of units of pressure which are currently used. Thus blood gas measurements will be given in the SI

$\begin{array}{ll}\text { Mass } & \text { kilogram }(\mathrm{kg}) \\ \text { Length } & \text { metre }(\mathrm{m}) \\ \text { Time } & \text { second (s) } \\ \text { Angle } & \operatorname{radian}_{(\mathrm{rad})} \\ \text { Area } & \text { metre }\left(\mathrm{m}^{2}\right) \\ \text { Volume } & \mathrm{metre}\left(\mathrm{m}^{3}\right) \\ \text { Velocity } & \mathrm{m} / \mathrm{s}^{3} \\ \text { Acceleration } & \mathrm{m} / \mathrm{s}^{2} \\ \text { Force = Mass } \times \text { Acceleration } & \mathrm{Newton}(\mathrm{N}) \\ \text { Energy, Work = Force } \times \text { Distance } & \mathrm{Joule}(\mathrm{J}) \\ \text { Power } & \text { Watt }(\mathrm{W}) \\ \text { Pressure, Stress } & \mathrm{Pascal}(\mathrm{P})=\mathrm{N} / \mathrm{m}^{2} \\ \text { Torque } & \mathrm{Newton} \mathrm{metre}(\mathrm{Nm}) \\ \text { Density } & \mathrm{kg} / \mathrm{m}^{3} \\ \text { Moment of Inertia } & \mathrm{kg} \cdot \mathrm{m}^{2} \\ \text { Dynamic Viscosity } & \mathrm{Ns} / \mathrm{m}^{2}=\mathrm{Pa} \cdot \mathrm{s} \\ \text { Kinematic Viscosity } & \mathrm{m} / \mathrm{s}\end{array}$

I am grateful for the help of the SI Units Working Party of the United Leeds Hospitals and to Mr. G. Johnson of the Bioengineering Group for the Study of Joints. unit $(\mathrm{kPa})$ instead of $\mathrm{mmHg} .1 \mathrm{mmHg}=133.32 \mathrm{~Pa}$ $1 \mathrm{kPa}=7 \cdot 5007 \mathrm{mmHg}$.

\section{WHAT WILL NOT CHANGE?}

(1) Haemoglobin: because of uncertainty concerning the elementary entity of haemoglobin that should be used for calculation of molar concentration, it has been agreed that for the time being haemoglobin concentration in blood will be expressed as mass concentration. The convention will be to use $\mathrm{g} / \mathrm{dl}$ (where $\mathrm{dl}$ is the SI symbol for $100 \mathrm{ml}$ ) so the numerical values will not change.

(2) At present no change is being made in the units for enzyme assays.

\section{CONVERSION TABLES}

For most laboratory data the main changes will be in haematology and chemical pathology. Conversion tables are appended and list, in alphabetical order, most of the frequently made measurements, and give some typical values in both SI units and in the units previously used, together with conversion factors and new normal ranges in Leeds. In the tables, the top row of figures are typical values in SI units, and beneath these are given the corresponding values in the present units. The column headed 'particle weight' refers to the atomic, ionic, molecular, or radical weight of the component and is used in deriving the conversion factors. The conversion? factor is used as follows: Value in old units $\times$ Factor $=$ Value in SI units or Value in SI units $\div$ Factor $=$ Value in old units. The following abbreviations are used: $\mathbf{B}=$ Blood, $\mathbf{C S F}=$ Cerebrospinal fluid, $\mathbf{F}=$ Faeces, $\mathbf{P}=$ Plasma or serum, $\mathrm{U}=$ Urine.

\section{BIOMECHANICAL DATA}

All imperial measurements, such as $\mathrm{lb}$ and inch, disappear. Likewise all c.g.s. (centimetre gramme second) units, such as dynes and ergs, go, and many units such as the M.K.S. (metre kilogram second) are also changed.

The following are the SI units used in the expression

$$
\begin{aligned}
1 \mathrm{lb} & =0.45359237 \mathrm{~kg} \\
1 \mathrm{inch} & =0.0254 \mathrm{~m} \\
1 \mathrm{degree} & =\pi / 180 \mathrm{rad} \\
1 \mathrm{in}^{2} & =645 \cdot 16 \mathrm{~mm} \\
1 \mathrm{in} 3 & =1 \cdot 63871 \times 10^{-5} \mathrm{~m}^{3} \\
1 \mathrm{ft} / \mathrm{s} & =0.3048 \mathrm{~m} / \mathrm{s} \\
1 \mathrm{ft} / \mathrm{s}^{2} & =0 \cdot 3048 \mathrm{~m} / \mathrm{s}^{2} \\
1 \mathrm{lbf} & =4 \cdot 44822 \mathrm{~N} \\
1 \mathrm{ft} \mathrm{lbf} & =1 \cdot 35582 \mathrm{~J} \\
1 \mathrm{ft} \mathrm{lbf} / \mathrm{s} & =1 \cdot 35582 \mathrm{~W} \\
1 \mathrm{lb} / \mathrm{in}{ }^{2} & =6 \cdot 89476 \mathrm{kPa} \\
1 \mathrm{lbf} \mathrm{ft} & =1 \cdot 35582 \mathrm{~N} \cdot \mathrm{m} \\
1 \mathrm{lb} / \mathrm{ft}^{3} & =16 \cdot 0185 \mathrm{~kg} / \mathrm{m}^{3} \\
1 \mathrm{lb} \mathrm{ft} t^{2} & =0 \cdot 0421401 \mathrm{~kg} \cdot \mathrm{m}^{2} \\
1 \mathrm{lb} \mathrm{s} / \mathrm{f}^{2} & =47 \cdot 8803 \mathrm{~Pa} \cdot \mathrm{s} \\
1 \mathrm{cStoke} & =10^{-6} \mathrm{~m}^{2} / \mathrm{s}
\end{aligned}
$$
of biomechanical data. 


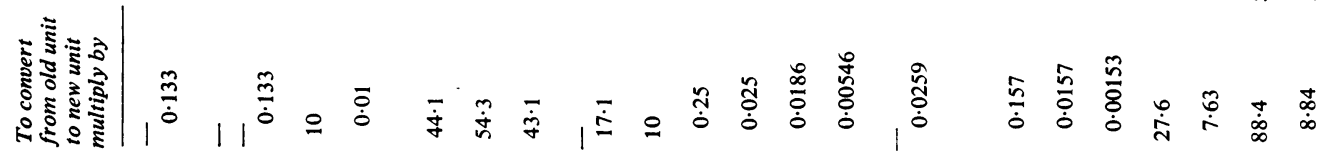

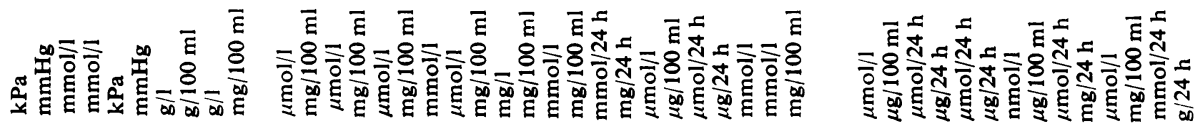

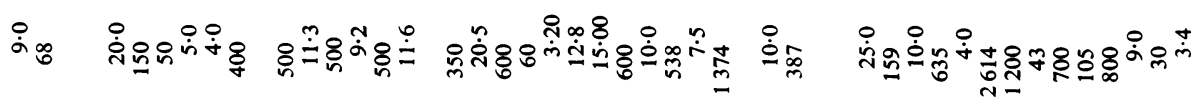
in

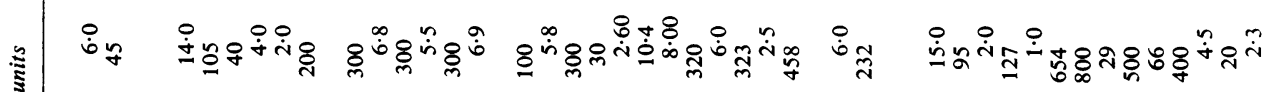

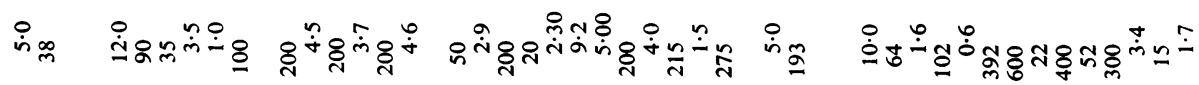

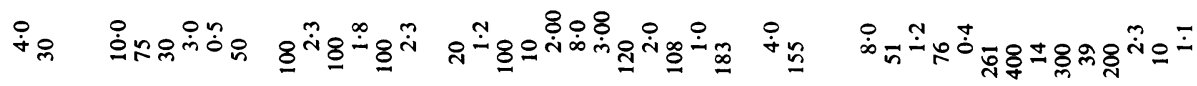

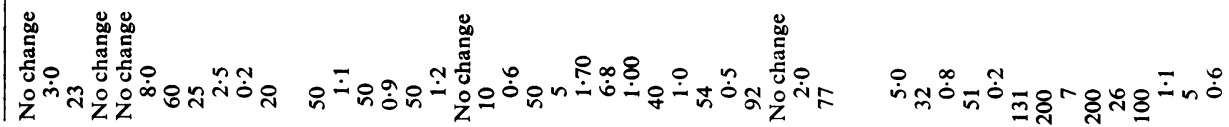

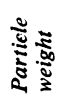

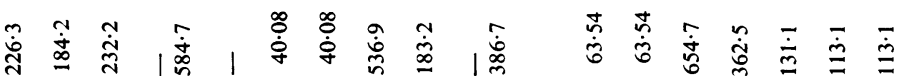
융 항용 


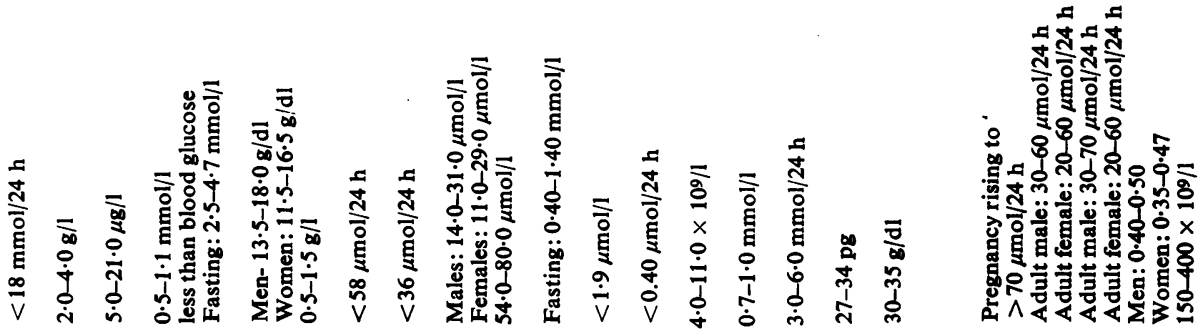

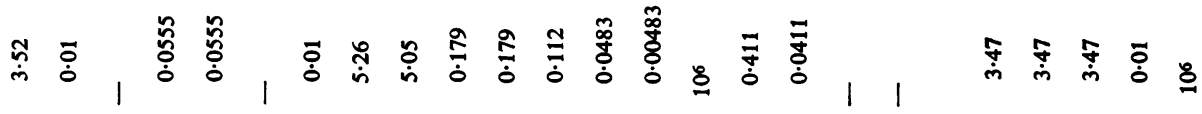

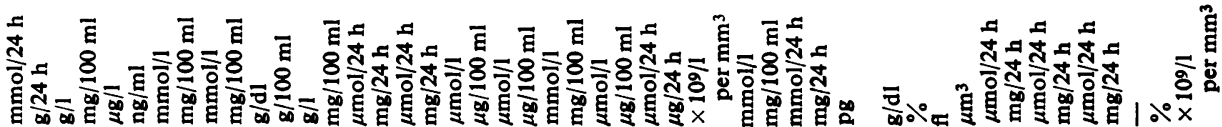
ळ

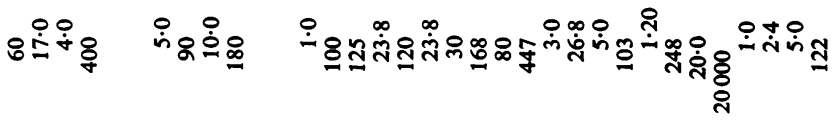

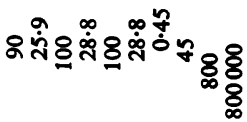

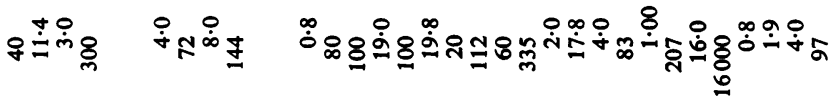

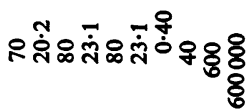

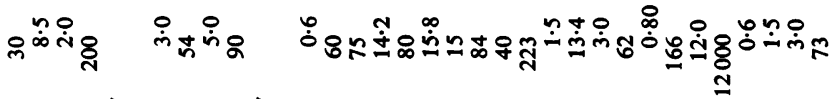

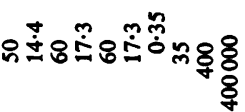

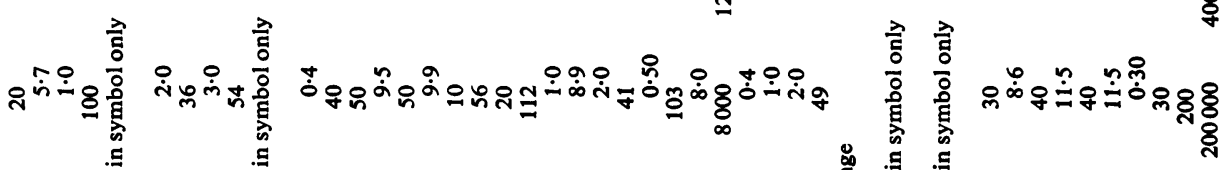

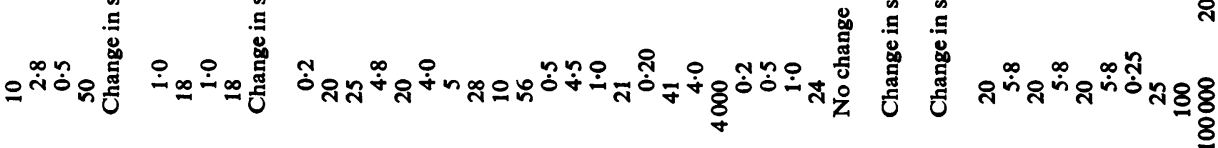

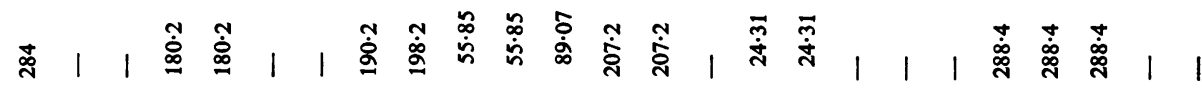

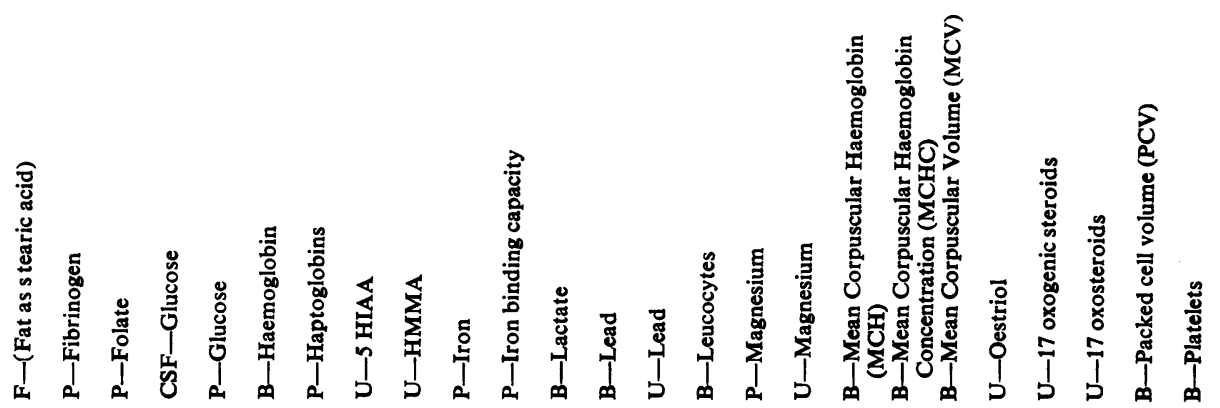


